\title{
THE EFFECT OF DIGITAL MATERIAL TOWARDS STANDARD TWO STUDENTS'S ACHIEVEMENT IN READING
}

\author{
Adenan Ayob \\ Associate Professor Dr., Sultan Idris Education University, MALAYSIA \\ adenansamsung@gmail.com
}

\begin{abstract}
Teaching and learning through digital technology is currently experiencing very rapid changes. Changes, especially in the reading system can be seen through the use of digital material with technology-based. To achieve that context, this research was carried out to test an interactive reading material for Standard Two primary school student. The experiment group was exposed to the use of interactive multimedia material, while the control group was exposed to the use of conventional material. Quasi-experimental method was used in this study to test Standard Two Student's achievement in reading comprehension. Data were analyzed by descriptive and inferential methods. Descriptive data are mean and standard deviation. Inferential data were analyzed using ANCOVA statistic. The result showed that there were significant difference between the use of interactive and conventional material when the pre-test is statistically controlled or covariates. The result shows the implication that interactive multimedia reading material makes student more creative and critical in reading. Therefore, it is proposed to the Ministry of Education, Malaysia to intensify the use of interactive multimedia materials in order to improve the achievement of student in reading.
\end{abstract}

Keywords: Digital material, achievement in reading, technology-based multimedia, interactive reading.

\section{RESEARCH BACKGROUND}

Reading means a process or understanding the meaning of the combined information derived from the text. Reading is also involved with existing knowledge through the background and experience (Gambrell \& Bales, 2012).

The education system is currently experiencing very rapid change. Changes in the system can be viewed through the use of interactive learning materials based on technology. Hedge (2010) argues that technology in education is a combination of people, equipment, techniques and events that aim to give a good impression to educate. Keller (2010) also pointed out that technology in education is the use of modern skills 
and techniques in training requirements. It includes the ease of learning that generates creative and critical thinking.

The importance of educational technology in teaching and learning is a smooth process that focused on the topics presented, saving time, energy and financial costs (Ministry of Higher Education Malaysia, 2011). In addition, educational technology can avoid boredom, thereby maintaining interest and entertains student. The effect of the use of technology can correct any confusion or misinterpretation as well as providing a comprehensive and clear overview of the concepts and their relevance to everyday life. Multisensory students generated a whole such as the use of audio-visual, followed by engaging the thinking senses. Educational technology can also make a difference and diversity to the teaching materials and to help student getting the maximum learning effect with minimum time consumption. The use of computer-based technology can also enrich student's experience. Loannis Deliyannis (2012) pointed out that the new innovation in education software making teaching more effective and meaningful.

\section{PROBLEM STATEMENT}

The few studies on reading comprehension concluded that the main factors contribute are the ability to experience, appreciate, while the ultimate goal is to understand something student's read (Gambrell \& Bales, 2012). This includes factor of memory, attention and appreciation of the material; linguistic skills: vocabulary, existing knowledge, teaching and learning strategies, the ability to interpreting the word and motivation.

Obviously, teaching and learning of reading among school students do not emphasize the aspects of understanding (Gambrell \& Bales, 2012). This is because teacher focuses on the important element that is to read fluently. This scenario is supported by Hsu, Wang and Hamilton (2011) that notes a fairly conventional approach in reading is too dominant in pedagogy. Traditionally perspectives also reviewing reading as a static approach (Lukman \& Krajnc, 2012). Students started reading from letter recognition and sound, followed by words and sentences until they are able to read fluently, but do not emphasize to understand through educational activities. Understanding through educational activities is said to be a top level in the hierarchy of reading. Thus, student is unable to reach this stage while not dominate the ground level (Hsu, Wang \& Hamilton).

In the traditional method of teaching and learning reading that occurs in the early stages, student still ignoring the ability of forming integration and instead emphasize the interactive materials (Gambrell \& Bales, 2012). Therefore, students are not exploited by the use of instructional strategies that based on interactive, creative and innovative materials.

In reading, the cognitive load occurs because the student had to identify different alphabet. Since the early stages of teaching reading was so dominated by certain model, then the learning do not gained student to memorize and understand.Generally, the teaching and learning of early reading levels is a difficult process to be controlled and implemented, rather than to challenge because reading must be based on the digital teaching materials (Gambrell \& Bales, 2012).

Therefore, this research tried to study the effect of digital material towards standard two student's achievement in reading. Quasi-experiment method that based on quantitative design was used in this research. The inferential data was analyzed by using ANCOVA statistic.

\section{RESEARCH OBJECTIVE}

This study was undertaken to test interactive reading materials for standard two students. Specific objectives are to identify:

i. the reading comprehension achievement for Standard Two students after using conventional and interactive reading materials; and

ii. whether there isa significant difference in terms of reading comprehension achievement for Standard Two students after using conventional and interactive reading materials. 


\section{RESEARCH QUESTION}

From both the specific objectives above, the research questions are formulated. The research questions are as follows:

i. What are the pre-test and post-test mean scores of reading comprehension achievement for Standard Two students after using conventional and interactive reading materials?

ii. Is there any significant difference in terms of reading comprehension achievement for Standard Two students after using conventional and interactive reading materials?

\section{LITERATURE REVIEW}

Upon advances on information technology in some existence smart schools, responsible authorities have to reconsider the appropriateness of digital materials to be used in the classroom, especially for the Malay Language as a core subject in primary and secondary schools. This scenario has also forced the curriculum department to examine the use of innovative materials in teaching and learning for future smart schools.

When refer to the mentalist group, student is said to be a natural efficiency and performance in learning and doing exercise regarding reading skill. Actually, reading skill is in the formulas or in a person's mental, especially the concept of knowledge that include content, language and overall comprehension. Performance is a measurement of achievement that based on knowledge in reading (Hedge 2010). In other words, the performance is a result of reading, student's knowledge and competence in content, language and overall comprehension. In order to produce passages in the reading, efficiency is the key criteria in assessing the final output. Accordingly, the reading process must be able to stimulate student to use creative and analytical abilities to formulate thinking in order to understand (Hedge 2010). In the process of reading, teacher acts as a consultant to determine whether there is a formation of attempts by student.

Mentalist theories also emphasized that there is an existed close relationship between reading and thinking (Hedge 2010). Therefore, when one reads, thought needs to be focused towards the articulation of sentences grammatically and meaningfully. According to the mentalist theory too, the grammatical knowledge consciously applied in reading, either inductive or deductive because student is capable of forming sentences grammatically and meaningfully (Khamurang, 2011). Formulas must include a description of sound. This principle is a major stake for them because among mentalist, reading passed through the process of thought. Interactive based learning in reading also encourages creative and analytical thinking.

Parveen and Rajesh (2011) have conducted a study on digital materials that based on multimedia for Standard One Students. The result showed that the students were able to intensify knowledge freely. Student who has paid attention can focus on learning. It also shows that the academic changes have occurred within a short period.

Malay Language is a subject that is considered difficult by most students in the classroom. They consider that to obtain the best scores requires knowledge and skills in using digital materials. This is because in teaching, there are some specification guidelines that to be practiced by a teacher (Adenan Ayob \& Khairuddin Mohamad, 2012).

\section{METHODOLOGY}

\subsection{Research Method}

In this study, quasi-experiment method is used. This method was based on quantitative research design. Subjects were from existing groups that have been determined by the school or intact group. Subjects were not randomly selected if they are from an intact group (Campbell \& Stanley, 1963).

Pre-test and post-test controlled group that was used in this study was derived from Fraenkal and Wallen (2009) ideas. Research designed is shown in Table 1. 
Table 1. Research design.

\begin{tabular}{|c|c|c|c|}
\hline Group & Pre-test & Material & Post-test \\
\hline Experiment & O1 & $\begin{array}{r}\mathrm{X} 1 \\
\text { Interactive }\end{array}$ & $\mathrm{O} 2$ \\
\hline Control & O3 & $\begin{array}{c}\mathrm{X} 2 \\
\text { Conventional }\end{array}$ & O4 \\
\hline
\end{tabular}

Legend:

$\mathrm{O} 1 \& \mathrm{O} 3=$ Pre-test

$\mathrm{X} 1=$ Interactive Reading Material

$\mathrm{O} 2$ \& $\mathrm{O} 4=$ Post-test

X2 = Conventional Reading Material

In this study, a sample selection was conducted among standard two students. Pre-test measures student's reading comprehension is described by $\mathrm{O} 1$ and $\mathrm{O} 3$, while the post-test described by $\mathrm{O} 2$ and $\mathrm{O} 4$. Subscript $\mathrm{X} 1$ (interactive reading materials) and X2 (conventional reading materials) refers to the using of the different materials.

\subsection{Data Analysis}

In quasi-experiment, data were collected from the pre-test and post-test. After all instruments acquired, the encoding process is done to facilitate the entry of data in SPSS Version 20. The process of data analysis involves two kinds of statistics; descriptive and inferential. Descriptive statistics used are mean and standard deviation. Statistical inference was used for reporting survey mean score difference by ANCOVA. Refer to Table 2.

Table 2. Data analysis.

\begin{tabular}{|l|l|l|}
\hline No. & \multicolumn{1}{|c|}{ Research Question } & \multicolumn{1}{c|}{ Statistic } \\
\hline i. & $\begin{array}{l}\text { What are the pre-test and post-test mean scores of reading } \\
\text { comprehension achievement for standard two students after } \\
\text { using conventional and interactive reading materials? }\end{array}$ & $\begin{array}{l}\text { Descriptive: } \\
\text { Mean and Standard Deviation }\end{array}$ \\
\hline ii. & $\begin{array}{l}\text { Is there any significant difference in terms of reading } \\
\text { comprehension achievement for standard two students after } \\
\text { using conventional and interactive reading materials? }\end{array}$ & $\begin{array}{l}\text { Inferential: } \\
\text { ANCOVA }\end{array}$ \\
\hline
\end{tabular}

\section{FINDING}

\subsection{Respondent Demography}

The experimental group used interactive reading material. The control group used conventional reading material. The experiment group is 15 students $(16.7 \%)$ in the state of Perak. The control group is also 15 students $(16.7 \%)$ in the same state. There were 30 students involved in this study.

\subsection{Is there any significant difference in terms of reading comprehension achievement for standard two students after using conventional and interactive reading materials?}

Table 3 presents the analysis of covariance. See the table below: 
IJAEDU- International E-Journal of Advances in Education, Vol. 3, Issue 8, August 2017

Table 3. Analysis of covariance.

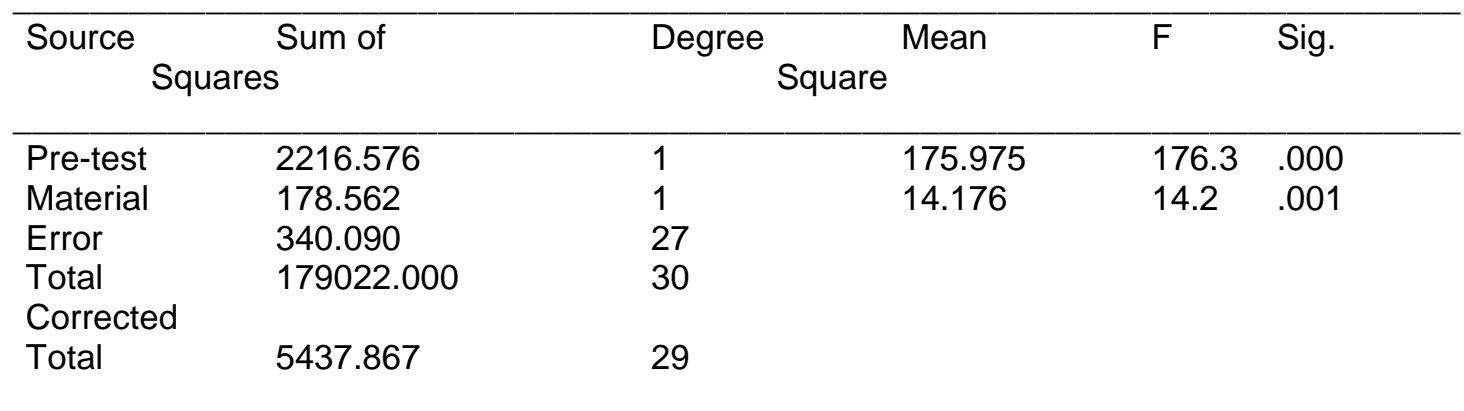

Table 3 shows $F(1,27)=14.2$, with a significance level $<0.05$. This shows that there is a significant difference between interactive and conventional material when the pre-test is statistically covariates.

\section{DISCUSSION AND IMPLICATION}

From the finding it can be concluded that there is a significant difference when student was exposed to interactive and conventional material and the pre-test is statistically controlled. This finding also support previous research finding on reading comprehension in English that based on multimedia interactive material (Gambrell \& Bales, 2012).

Interactive reading materials will help student to improve achievement may be associated with the main properties of using an application. Reading activities must run the interactive nature of reading material, online access, electronic publication and dissemination of information globally. For example, with it is the dissemination of information, student can improve their knowledge in reading and encouraging reading achievement (Hsu, Wang \& Hamilton, 2011). This finding is also associated with the Piaget (1963) opinion that student achievement is good when learning scenarios triggering a full opportunity to add extensive knowledge.

The finding of this study also supports Lukman and Krajnc (2012) ideas that the use of multimedia interactive learning activities in reading provides a valuable global environment that stimulates creative thinking in comprehension. According to Premawardhena (2012), the use of interactive multimedia is considered a favorable reading. Premawardhena also stated that computer helps student to access global sources of knowledge to suit the content in reading (Kittidachanupap, Singthongchai, Naenudorn \& Khopolklang, 2012). They also briefly interpreted that the use of interactive multimedia material is to strengthen efforts to gain the knowledge in reading, identify the accuracy of the contents and to assessing the validity of information that was aligned with certain topic.

Student performance in reading is also related to the variation in virtual activities. This statement appears from Nikolaraizi and Vekiri (2011) opinion that the vast knowledge obtained by students in the classroom helping their efforts in learning activities. This statement also coincides with learning theory and exposure of knowledge of the specific input from reading comprehension (Demirer \& Sahin, 2012).

Student's achievement in reading was also closely linked to the reading activities (Singh \& Mishra, 2016). Those activities can shape the student's skill to absorb a large volume that based on the integration of multimedia elements via technological content (Shis, Papa, Chang \& Hsin, 2012). By using information technology, student can learn particular aspect in reading to suit such a topic (Kittidachanupap, Singthongchai, Naenudorn \& Khopolklang, 2012). Student also can be taught to use them correctly and accurately through observation by concrete understanding on comprehension.

This finding also supports the decision made by Islam, Baharul Islam, Kabirul Ahmed and Shamsuddin (2013), which responds to the efforts of student to keep reading that was boosted by the integration of pedagogical content via accessing information. With the guidance of the important contents and reasoning in reading, student has variations in understanding the basis of specific activities (Grabe \& Stoller, 2011). This procedure is considered essential for producing excellent achievement in reading comprehension.

The achievement and quality are closely connected to the thinking skills through right idea, concise and pithy. According to Grabe and Stoller (2011), the competitiveness of thinking in reading is driven by intrinsic 
motivation when using interactive multimedia material that based on certain activity.

Video is also suitable for student to stimulate quality of reading comprehension through cooperative spirit, intuitive with the assistance of digital and virtual environment (Dembo \& Seli, 2012). This opinion also supports the mentalist ideas that reading activities is an intuitive process to transform abstract into concrete symbols in an active and proactive environment (Dembo \& Seli). Gambrell and Bales (2012) also agreed with Dembo and Seli that reading was reflected by fostering confidence and boost student's thinking actively. Gambrell and Bales added that student easily understand the concept and meaning when guided intuitive reading process via multimedia integration-based material. It is also usable to generate a strong conclusion about the output of reading.

\section{DECISION AND CONCLUSION}

The Ministry of Education (MOE), Malaysia should review the need to equip classrooms with computers, including the facilities of internet. The purpose is to provide student's convenience in order to gain maximum benefit from the flow of information technology-based learning. Infrastructure equipment is also very important to ensure that students are always interested in learning via digital and virtual environment.

To encourage student to use interactive reading materials in the classroom, teacher's expertise in the field of information technology is essential. The rule in reading comprehension should be in line with specific expertise on information technology. So, MOE should open up opportunities for primary school teacher to enhance their knowledge and expertise in the field of computer and information technology through intensive courses.

\section{REFERENCE LIST}

Adenan Ayob \& Khairuddin Mohamad (2012). Methods of teaching Malay Language. Oxford Fajar: Shah Alam, Selangor.

Campbell, D. T., \& Stanley, J. C. (1963). Experimental and quasi-experimental designs for research on teaching. In N. L. Gage (Ed.), Handbook of research on teaching (pp. 171-246). Chicago, IL: Rand McNally.

Dembo, M. H. \& Seli, H. (2012). Motivation and learning strategies for college success: $A$ focus on self regulated learning. NY: Erlbaum.

Fraenkel, Jack R. \& Norman E. Wallen (2009). How to Design and Evaluate Research in Education. New York. McGraw-Hill Companies.

Gambrell, L. B., \& Bales, R. (2012). Mental Imagery and the Comprehension-monitoring Performance of Fourth and Fifth Grade Poor Readers. Reading Research Quarterly, 21(4), 454-464.

Grabe, W. \& Stoller, F. L. (2011). Teaching and researching reading. Harlow: Pearson Education Limited.

Hedge, T. (2010). Teaching and learning in the language classroom. Oxford: Oxford University Press.

Hsu, J., Wang, Z. \& Hamilton, K. (2011). Developing and Managing Digital/ Technology Literacy and Effective Learning Skills in Learning. International Journal of Digital Literacy and Digital Competence (IJDLDC), 2(1).

Islam, M. Baharul Islam, M. Kabirul Ahmed, \& Shamsuddin, A. Kalam (2013). Interactive Digital Learning Materials for Kindergarten Students in Bangladesh. Proceedings of 2nd International Conference of System Modeling and Advancement of Research Trends (2nd SMART 2013), 15-16 November 2013, Teerthankar Mohaveer University, India.

Keller, J. M. (2010). Motivational design for learning and performance: The ARCS model approach. New York: Springer.

Khamurang, A. R. (2011). The Role of ICTs in Enhancing the Quality of Preschooler Education Concerns and Issues. RIE. NCERT. Bhubaneswar. Odisha. 123-127. www.riebbs.ori.nic.

Loannis Deliyannis (2012). Interactive multimedia. Croatia: In Tech. 
Lukman, R., \& Krajnc, M. (2012). Exploring Non-traditional Learning Methods in Virtual and Realworld Environments. Educational Technology \& Society, Vol. 15, no. 1, 237-247.

Ministry of Higher Education Malaysia, MOHE. (2011). Blueprint on enculturation of lifelong learning for Malaysia 2011-2020. Malaysia: Univision Press.

N. C. Premawardhena (2012). Introducing Computer Aided Language Learning to Sri Lankan Schools: Challenges and Perspectives. 15th International Conference on Interactive Collaborative Learning (ICL), Sept. 26-28, Location (N/A).

N. Kittidachanupap, J. Singthongchai, E. Naenudorn \& N. Khopolklang (2012). Development of Animation Media for Learning English Vocabulary for Children. IEEE International Conference on Computer Science and Automation Engineering, May 25-27, Zhangjiajie, China.

Nikolaraizi, M., \& Vekiri, L. (2011). The Design of Software to Enhance the Reading Comprehension Skill: An Integration of Multiple Theoretical Perspectives. Education and Information Technologies, DOI: 10.1007/s10639- 011-9152-1.

Parveen, J. J., \& Rajesh, V. (2011). Multimedia in English Language Teaching: An Empirical Study. Journal of Technology for ELT, 1(4).

Piaget, J. (1936). Origins of intelligence in the child. London: Routledge \& Kegan Paul.

R. Shis, C. Papa, M. Chang, \& T. Hsin (2012). Effect of Incorporating Project-Based Learning into the Development of an English Short Play for Children. IEEE fourth International Conference on Digital Game and Intelligent Toy Enhanced Learning (DIGITEL), March 27-30, Takamatsu. 